\title{
Public health emergency, UNEP environmental assessment and the clean-up of Nigeria's Niger delta
}

\begin{abstract}
There is a growing recognition of the critical need to clean up oil spills and other oilrelated pollution in Nigeria's Niger Delta in order to avert a looming public health disaster. Immediately after the United Nations Environmental Program (UNEP) published its landmark report on the environmental assessment of Ogoniland in Nigeria's Niger Delta in August 2011, there was global optimism that the Nigerian government might finally act to clean up the area's environment heavily polluted by decades-old oil spills. Upon receiving the report, the government of Goodluck Jonathan promptly constituted the Hydrocarbon Pollution Restoration Project (HYPREP) agency to oversee the cleanup project. Further action was stalled and the severe pollution-related environmental and public health challenges enumerated in the report persist in the Niger Delta. The 2015 election of Mohammedu Buhari, who was widely perceived as a reformer, rekindled belief that the clean-up program might finally be implemented. This paper discusses the factors that contributed to the non-implementation of the report, as well as the measures the government of Mohammedu Buhari has taken to get the report finally implemented.
\end{abstract}

Volume 2 Issue 6 - 2018

\author{
Isidore A Udoh \\ Health Sciences and Physical Education, College of Education, \\ Northeastern Illinois University, USA
}

Correspondence: Isidore A Udoh, Health Sciences and Physical Education, College of Education, Northeastern Illinois University USA, Email i-udoh@neiu.edu

Received: February 16, 2018 | Published: December 20, 2018

\section{Introduction}

The United Nations Environmental Program (UNEP) Environmental Assessment of Ogoniland report ${ }^{1}$ published on August 4, 2011 drew global attention to the public health disaster caused by oil-related pollution in Nigeria's Niger Delta region. The UNEP assessed that oil spills and gas flaring, which occur annually in the region (nearly 600 million gallons since oil production started in 1958) have often either been ignored or poorly removed by oil companies. Oil spills, in particular, have contaminated farmlands and destabilized crop yields, damaged mangroves and negatively impacted fish habitats and life cycles, brought suffering on the fisheries and farming sectors, and created food scarcity. Surface and ground water in the region is contaminated with hydrocarbons at levels 1,000 times higher than the Nigerian drinking water standard. In some areas, drinking water wells are contaminated with benzene "at levels nine hundred times above the World Health Organization (WHO) guideline."' This paper discusses the factors that have thus far impeded the implementation of the UNEP assessment report by the Nigerian government.

\section{Scope and public health cost of oil pollution in Nigeria}

Compared to other top world oil-producing countries, Nigeria's pollution profile ranks among the worst. ${ }^{2}$ A report published in 2006 by UNDP indicated that between the late 1970s and 2006 more than 400,000 tons of crude oil was spilled in the Niger Delta; $70 \%$ of this was not recovered. ${ }^{3}$ A recent study shows that in 2014 alone, Shell reported 204 oil spill incidents and Eni reported 349 spills. ${ }^{4}$ Nigeria flares more natural gas during oil production than any other top oilproducing country in the world except Russia (Table 1). Nigeria's oil industry (NNPC, ExxonMobil, Chevron, Shell, and ENI are the worst offenders) alone accounts for $10 \%$ of the total amount of natural gas flared globally and produces more greenhouse emissions in Africa than all other sources combined. ${ }^{2,5-7}$ Unsurprisingly, UNEP investigators found that about ten percent of airborne benzene detected in Ogoniland was "higher than the concentrations WHO and the United States Environmental Protection Agency report as corresponding to a 1 to 10,000 cancer risk." Numerous studies have argued that oil production in the Niger Delta has caused ground water pollution, noise pollution, ecosystem destruction, poverty, hunger, malnutrition, stress, sex work, elevated risk of sexually transmitted infections, ${ }^{5-9}$ violent conflicts, and deaths..$^{9-11}$ Although a robust assessment of the negative health impact of oil pollution in the Niger Delta is rare, studies have linked exposure to hydrocarbons in the Prestige and Sea Express oil spills to respiratory symptoms and chromosomal damage. ${ }^{12-14}$ Similarly, exposure to hydrocarbons in the BP Gulf oil spill in the United States has been associated with significant decrease in platelet counts, significant increase in the hemoglobin and hematocrit levels, and significantly higher levels of alkaline phosphatase (ALP), aspartate aminotransferase (AST), and alanine transaminase (ALT) ${ }^{15}$ Oil spills in the Niger Delta occur daily, involve a cumulatively larger volume of oil, and span nearly sixty years of oil production. It is quite plausible, therefore, to conclude that the damage to the environment and the public health impact of oil spill in this environment is quite significant.

Predictably, oil pollution has been partially blamed for a number of persisting public health challenges, including both high child and under-five mortality rates and a dismal life expectancy. ${ }^{16}$ Noting that Ogoniland can be remediated in 25-30 years, the UNEP urged the Nigerian government to act expeditiously to limit and remedy the health risk caused by oil pollution to the Niger Delta environment and people.

\section{Methodology}

This paper is an outcome of the author's longstanding engagement with issues related to oil production and human development in Nigeria's Niger Delta. Immediately following the release of the Ogoniland assessment report by UNEP in 2011, the author travelled to Port Harcourt in Nigeria's Niger Delta to discuss the findings of the report with key stakeholders in region's oil production. During this time, the author conducted semi-structured interviews with former Niger Delta militants, who had waged years of armed resistance against security personnel from multinational oil companies and the Nigeria's armed forces. The lead author also conducted focus group discussions among 85 representatives of oil producing communities, youth and women groups, civil society organizations, oil companies, media organizations, and local government. The interviews aimed to understand the impact of oil production, including environmental 
pollution, on communities in the area. They also interrogated the sources of and ideas for resolving oil-related conflicts and development challenges in the region. Following the initial visit, the author has made follow up visits to Nigeria and engaged multiple stakeholders, including UNEP, to encourage immediate action to clean up oil spills in the Niger Delta. The author has stayed engaged with stakeholders, even as Nigeria experienced a political transition from the government of Goodluck Jonathan to the administration of Mohammedu Buhari. The author recognizes that the new Nigerian government needed to act decisively to clean up the region in order to limit and, possibly, reverse the damage to the environmental and public health by decades of oil spills and gas flaring.

Table I Estimates of flared natural gas and key health outcomes among fifteen top world oil producers

\begin{tabular}{|c|c|c|c|c|c|c|}
\hline Country & $\begin{array}{l}\text { Total oil } \\
\text { production* }\end{array}$ & $\begin{array}{l}\text { Total oil } \\
\text { consumption* }\end{array}$ & $\begin{array}{l}\text { Total natural gas } \\
\text { Production+ }\end{array}$ & $\begin{array}{l}\text { Total natural gas } \\
\text { vented and Flared } * *\end{array}$ & $\begin{array}{l}\text { Infant (under-5) } \\
\text { mortality rates++ }\end{array}$ & $\begin{array}{l}\text { Life } \\
\text { expectancy } \\
\text { (years)^^}\end{array}$ \\
\hline $\begin{array}{l}\text { United } \\
\text { States }\end{array}$ & $12,342.77$ & $18,961.13$ & $24,333,709$ & 251 & $6(7)$ & 79 \\
\hline $\begin{array}{l}\text { Saudi } \\
\text { Arabia }\end{array}$ & $11,600.35$ & $2,925.00$ & $3,637.45$ & $13 \mid$ & $13(16)$ & 76 \\
\hline Russia & $10,533.74$ & $3,320.00$ & $21,358.51$ & 1,320 & $9(10)$ & 69 \\
\hline China & $4,459.41$ & $10,116.64$ & $4,135.39$ & 92 & $I I(I 3)$ & 75 \\
\hline Canada & $4,073.87$ & $2,431.28$ & $5,128,83$ & 85 & $5(5)$ & 82 \\
\hline Iran & $3,192.37$ & $1,870.00$ & $5,649.15$ & 402 & $14(17)$ & 74 \\
\hline $\begin{array}{l}\text { U.A. } \\
\text { Emirates }\end{array}$ & $3,229.59$ & 698 & $1,853.95$ & --- & $7(8)$ & 76 \\
\hline Iraq & $3,057.69$ & 769 & 22.81 & 332 & $28(34)$ & 70 \\
\hline Mexico & $2,907.83$ & $2,044.27$ & I,639.78 & 74 & $13(15)$ & 76 \\
\hline Kuwait & $2,811.84$ & 467 & 547.91 & --- & $8(10)$ & 78 \\
\hline Brazil & $2,693.87$ & $3,097.00$ & 752.21 & --- & $12(14)$ & 74 \\
\hline Venezuela & $2,489.24$ & 784 & $1,002.95$ & 124 & $13(15)$ & 76 \\
\hline Nigeria & $2,371.51$ & 302 & $\mathrm{I}, \mathrm{I} 90.48$ & 515 & $74(117)$ & 54 \\
\hline Qatar & $2,067.30$ & 220 & $5,523.25$ & 60 & $7(8)$ & 79 \\
\hline Norway & $1,826.10$ & 222.83 & $3,840.01$ & --- & $2(3)$ & 82 \\
\hline
\end{tabular}

*,Thousand Barrels per Day; ^, Million Metric Tons of CO2; ${ }^{+}$, Million Cubic Feet - 20I 3 estimates; **, Billion Cubic Feet - 20I I estimates; Sources: www.eia.gov and NOAA Satellite data; ^^,WHO Life expectancy at birth: Both sexes 20I2; ++,WHO Child mortality levels 2013.

\section{Global and local responses}

The UNEP recommended that the Nigerian government implement urgent environmental remediation measures to limit the adverse ecological impact resulting from oil exploration in this region. After the Goodluck Jonathan government received the report in August 2011, they constituted the Hydrocarbon Pollution Restoration Project (HYPREP) and appointed Diezani Alison-Madueke, then petroleum minister, to direct the agency's mandate to make recommendations "on immediate and long-term remedial actions to fully implement the United Nations Environment Programme's Assessment Report on Ogoniland." ${ }^{16,17}$ Beyond the constitution of HYPREP, however, the Goodluck Jonathan government had been hesitant to implement the report. The focus of his government quickly shifted to other political challenges, including violent conflicts involving the fundamentalist Islamist group - Boko Haram, a fiercely contested election, power shift and transition, and the drop in federal revenue resulting from declining oil prices and rampant corruption. Even then, the UNEP continued to encourage the government to keep the implementation of the Ogoni assessment report among their top priority programs.
Although the UNEP has exerted influence to promote the cleanup proposal, many stakeholders in the Niger Delta oil producing communities have questioned UNEP's ability to persuade the Nigerian government to implement the report. Given government's reluctance to act, many have come to view this report as one among many such reports undertaken at the behest of the Nigerian government, but ultimately only serving as symbolic gestures aimed to silence vocal critics, pacify restive communities, and keep oil flowing in the Niger Delta. ${ }^{11,18}$ Many oil-producing community representatives we interviewed in December 2012, for example, echoed this skepticism; ${ }^{10}$ others held out hope that this report could be different- that the Nigerian government and oil companies could finally act - because the world community had called for urgent action to curb current and proximate public and environmental health impact of oil-related pollution in the Niger Delta. Our outreach to the UNEP in 2014 echoed the same confidence in the apparent goodwill of the Jonathan administration to act on the UNEP report through HYPREP. The lack of progress on implementation of this report could be attributed to a number of factors that relate to Nigerian politics. 
The implementation was hampered by a months-long struggle for control over the clean-up program between the federal ministry of petroleum resources and the federal ministry of environment. Although the ministry of environment appeared to be the sensible and natural platform for managing the clean-up program, the ministry of petroleum resources insisted on being in-charge. ${ }^{17}$ The National Oil Spill Detection and Response Agency (NOSDRA), which was created within the ministry of environment by the country's national assembly in 2006, had been given the mission to "restore and preserve the environment by ensuring best oil storage and transmission practices in exploration, production and use of oil in the quest to achieve sustainable development in Nigeria." ${ }^{19}$ NOSDRA, thus, appeared to be the obvious competent agency to manage the cleanup program. Yet, the ministry of petroleum resources, headed by Diezani AlisonMadueke, was determined to exercise control of the program. Although many worried that Madueke's past as a former employee of Shell (accused of causing most of the pollution in Ogoniland) and her role as oil minister and de facto head of the Nigerian National Petroleum Corporation (also accused of polluting the area) might represent a conflict of interest, many stakeholders were willing to work with the minister to get the cleanup program underway. ${ }^{20-23}$ When we contacted HYPREP in June 2014, it was clear that the agency was disintegrating. It had no specific office location, staff had no clear mandates, and they expressed frustration that their salaries had not been paid for several months since hiring. The raft of activities that Alison-Madueke presided over with leaders of Ogoniland and other stakeholders close to the general elections appeared to carefully orchestrated actions aimed at securing support for Jonathan's reelection as the 2015 elections drew closer. ${ }^{24}$ Shortly after Jonathan lost the election, Alison-Madueke exiled herself to England where she was subsequently arrested on suspicion of fraud and money laundering. ${ }^{25}$

Buhari made firm promises before and after his election victory to swiftly initiate the cleanup program. On August 5, 2015, approximately three months after winning the election on May 29th of the same year, Buhari's government announced a reconstitution of HYPREP on what they considered to be a more transparent and participatory platform of governance. ${ }^{26}$ On the reconstituted agency, both the ministries of petroleum and environment are equally represented; oil companies, UNEP, Ogoniland, and Rivers State are also represented. Buhari's actions significantly raised the hopes of the Ogoni community that the cleanup exercise would soon commence. Yet the Buhari government has continued with the ineffective Jonathan-era policy of housing this agency within the ministry of petroleum resources, the most politicized ministry in the Nigerian government. Not surprisingly, the political cat and mouse game between Ogoniland and the Nigerian government continues, stoking widespread anger and frustration. ${ }^{27}$ Recent appeals to the affected Niger Delta communities by the United Nations to exercise patience and wait for the Nigerian government to act, after six years of unfulfilled promises and ineptitude, are beginning to ring hollow to these increasingly skeptical stakeholders. ${ }^{28}$

\section{Conclusion}

Although many Nigerian people welcome the Buhari government's promise to implement the Ogoniland oil cleanup program, most Nigerians remain skeptical, given that past governments that made similar promises to restore the Niger Delta environment ultimately failed to fulfill them. Especially in the Niger Delta, distrust of the Nigerian government runs deep, given the history of neglect and repression many associate with government and oil companies. The tragedy of this political back and forth is that the longer the cleanup program is delayed, the more degraded the environment around the oil producing communities become. In 2011 the UNEP report warned that a large portion of the Niger Delta ecosystem has been rendered uninhabitable and urged the Nigerian government to urgently evacuate several communities in areas where underground and surface water was heavily contaminated by hydrocarbons. No action has been taken to evacuate those communities or protect the health of the inhabitants. The challenge for the Buhari government will be mobilizing sufficient resources necessary to undertake an extensive and expensive restoration project when oil prices and oil-related revenues are in decline. Yet, the risk of failing to implement the report could be quite expensive for Nigeria while still grappling with a deadly Islamist revolt in the North, a separatist Biafra movement in the Southeast, and a resurgence of oil-based militancy in the Niger Delta.

\section{Acknowledgment}

None.

\section{Conflicts of interest}

The author declares that there is no conflict of interest.

\section{References}

1. UNEP. Environmental Assessment of Ogoniland. 2011.

2. USEIA. Nigeria analysis. 2014.

3. UNDP. Niger Delta Human Development Report. 2016.

4. Amnesty International. 2016.

5. Borzello A. Nigeria court action on flaring. BBC News. 2005.

6. Quist-Arcton O. Gas Flaring Disrupts Life in Oil-Producing Niger Delta. NPR. 2007.

7. Farina MF. Flare gas reduction: Global trends and policy considerations 2014.

8. Aghedo I. Winning the war, losing the peace: amnesty and the challenges of post-conflict peace-building in the Niger Delta, Nigeria. Journal of Asian and African Studies. 2013;48(3):267-280.

9. Udoh IA. Oil, Migration, and the Political Economy of HIV/AIDS Prevention in Nigeria's Niger Delta. International Journal of Health Services. 2013;43(4):681-697.

10. Udoh IA. A Qualitative Review of Militancy, Amnesty, and Peace Building in Nigeria's Niger Delta. PEACE RESEARCH: The Canadian Journal of Peace and Conflict Studies. 2013;45(2):63-93.

11. Udoh IA, Ibok MS. Manipulative and coercive power and the socialecological determinants of violent conflict in the Niger Delta of Nigeria. African Conflict and Peacebuilding Review. 2014;4(1):60-94.

12. Lyons RA, Temple JM, Evans D, et al. Acute health effects of the Sea Empress oil spill. Journal of Epidemiology and Community Health. 1999;53(5):306-310.

13. Rodríguez-Trigo G, Zock JP, Pozo-Rodríguez FP, et al. Health Changes in Fishermen 2 Years After Clean-up of the Prestige Oil Spill. Annals of Internal Medicine. 2010;153(8):489-498.

14. Zock JP, Rodriguez-Trigo G, Pozo-Rodriguez F, et al. Prolonged respiratory symptoms in clean-up workers of the prestige oil spill. American Journal of Respiratory and Critical Care Medicine. 2007;176(6):610-616.

15. D'Andrea MA, Reddy GK. Health consequences among subjects involved in Gulf oil spill clean-up activities. The American journal of medicine. 2013;126(11):966-974. 
16. UNEP. UNEP in Ogoniland newsletter. 2011.

17. UNEP. UNEP welcomes Nigerian government's green light for Ogoniland oil clean-up. 2014

18. Report of the technical committee on the Niger Delta. 2014.

19. NOSDRA. 2014

20. Baird J. Oil's shame in Africa. Newsweek. 2010;156:27.

21. Shosanya M. Nigeria: 'Petroleum Minister Not Fit to Constitute Committee on Ogoni Clean-Up'. 2014.

22. Balch O. Shell is pushed to explain its role in $\$ 1.1 \mathrm{bn}$ Nigerian corruption scandal. The Guardian. 2014.
23. Ross W. Is Nigeria serious about tackling corruption? BBC News. 2014.

24. International Crisis Group. Curbing violence in Nigeria (III): Revisiting the Niger Delta. 2015.

25. BBC. Nigeria's ex-oil minister 'arrested in London'. 2015.

26. Buhari approves actions to fast-track environmental clean-up of Ogoniland. Point Blank News. 2015.

27. Ibekwe N. Special report: Disappointment, anger in Ogoniland over Nigerian government's delay to clean up oil spills. Premium Times News. 2017.

28. Chinwo E. Ogoni Clean-up: United Nations appeals for patience. This Day. 2017. 